\title{
Boy Scouts, the National Rifle Association, and the Domestication of Rifle Shooting
}

\author{
Jay Mechling
}

In the action film, Spy Game (2001), the CIA agent played by Robert Redford asks Brad Pitt's character where he learned to shoot so well. "In the Boy Scouts," replies Pitt's character, dead serious. And so did I, and so did tens of thousands, perhaps hundreds of thousands, of other boys. In Tim O'Brien's first memoir of the Vietnam War-If I Die in a Combat Zone (1975) - he confesses he also learned to shoot in the Boy Scouts. ${ }^{1}$ My experience was all target shooting or, in some cases, skeet shooting, with .22 caliber single-shot shotguns-a sport in which, personally, I harmed not a single clay pigeon. I never shot a gun again until the summer of 2006, a good forty-seven years later, when once again I loaded, aimed, and fired a .22-short rifle at a Boy Scout camp and did pretty well. My body and mind remembered the earlier experiences, the quiet concentration of the aim, gently squeezing the trigger rather than pulling it, and then catching a whiff of gunpowder and hot brass as I worked the bolt to eject the spent shell and insert a new bullet into that small hole. Slide the bolt forward, lock, prime the firing pin, and begin the concentration all over again. Power, danger-as exciting to the man as to the boy.

Thinking about the Boy Scouts and guns brings conflicting images to mind. For critics of the Boy Scouts of America (BSA), critics who see the BSA as a paramilitary organization, rifle training seems to fit the image of little brownshirts doing marching drills and practicing violence with firearms. For those who see the Boy Scouts as an organization advocating world brotherhood and 


\section{Jay Mechling}

an appreciation of the living world, rifle shooting seems oddly inappropriate. Parents, already worried about the toy guns and first-person shooter video games their pre-adolescent sons embrace, must cringe when the postcard from Scout camp relates their son's day on the rifle range.

The image of pre-adolescent and adolescent boys shooting rifles at Boy Scout camp evokes especially complex feelings in the wake of mass shootings in safe suburban and school settings. A series of school shootings and the daily gang-related shootings and deaths in urban areas in the 1990s began to fuel the moral panic about adolescent boys, aggression, and gun violence. Filmmaker Michael Moore's Bowling for Columbine (2002), the Academy Award-winning documentary about the Columbine High School shooting in Colorado in 1999, indicts the National Rifle Association (NRA) for creating easy access to the sorts of guns used by students Harris and Klebold in that mass shooting. The massacre at Sandy Hook Elementary School in Newtown, Connecticut, on December 14, 2012, shocked the nation enough to spark an intense debate about guns in American culture, but that tragedy - in which twenty children and six adults died at the school-came on the heels of a mass shooting a few months earlier in a movie theatre in Aurora, Colorado. Again, the NRA found itself pitted against gun control organizations (or "gun safety" organizations, as they prefer to be called now), from the decades-old Brady Campaign to Prevent Gun Violence to the more recent Political Action Committee created by New York City Mayor Michael Bloomberg and to Americans for Responsible Solutions, created by former representative Gabby Giffords, herself the victim of a mass shooting during an event at her home district in Arizona in January of 2011. In none of the debate over guns and the NRA has the century-long partnership between the NRA and the BSA been raised.

Although these shootings raise many issues for public debate - including issues of gender, social class, ethnicity, the sociobiological roots of male aggression, the easy access by children and adolescents to extremely dangerous weapons, the effects of popular culture on teen violence, and the adequacy of mental health detection and treatment programs - these are not my topic here, except as my focus on the BSA narrows the inquiry by gender and social class. ${ }^{2}$ Boys may be drawn naturally to guns and gunplay, but culture shapes that attraction. ${ }^{3}$

The rifle marksmanship program within the BSA was not an inevitable part of the Scouting program. A number of social and historical forces converged at the founding of the BSA in 1910 to make rifle shooting seem a natural part of being a Boy Scout. By and large, Boy Scouts came not from rural areas, where hunting and a culture of gun safety and use were taken for granted. Instead, gun use had to be naturalized and domesticated for the urban and suburban boys who constituted the main membership of the white, middle-class organization. These boys had to be socialized into gun use, and they and their parents had to be persuaded that learning the safety and shooting skills required of marksmanship training served the character-building goals of the organization. 
In his famous farewell address on January 17, 1961, President Eisenhower warned of the growing power of the military-industrial complex, an "iron triangle" of institutions - the Pentagon, the arms manufacturers, and the special interests in Congress - threatening to control the United States and threatening to push the United States toward war rather than peace. ${ }^{4}$ A similar iron triangle emerged in the first decade of the twentieth century, as the National Rifle Association, the Boy Scouts of America, and the gun and ammunition manufacturers (including air gun manufacturers) collaborated to ensure that as many young Americans as possible were trained to accept guns as playing a necessary part in a larger story about American independence, self-reliance, and virtue. These institutions forged a set of meanings connecting rifle marksmanship, masculinity, and patriotism.

Boys raised in rural areas commonly learned to hunt with rifles in the eighteenth and nineteenth centuries, though some historians dispute whether hunting was as pervasive as the frontier mythology claims. ${ }^{5}$ This much is certain - with the late nineteenth-century sense of the closing of the frontier (as Frederick Jackson Turner declared in 1893) and the increased urbanization of American life, the power of the frontier myth and the power of sport hunting as the symbolic performance of masculinity, self-reliance, and democracy increased. Theodore Roosevelt embodied this new mythology linking hunting with masculinity and nationality. ${ }^{6}$ The Boone and Crockett Club was founded in New York City in 1887 to foster in the "better" classes the masculine virtues to be learned and performed in sport hunting.

But youth movements in the United States in the late nineteenth century were less concerned with rural boys and their subsistence hunting, or elite urban boys and their sport hunting, than they were with increasingly troublesome urban boys. Whatever their origins - as European immigrants, as migrants to cities from rural areas, or simply as a new generation of urban street kids - the boys of the 1880s and 1890s needed saving from urban ills and in some cases needed to be "Americanized" as well. Whatever the virtues of hunting for forging republican masculinity, hunting was not to be the salvation of urban boys. Rather, some individuals and organizations began to tout the value of rifleshooting at targets ("marksmanship") as an activity suitable for creating and maintaining physical fitness, mental alertness, a competitive spirit, and democratic camaraderie in American boys. The idea of a "muscular Christianity" not on the playing fields but on the shooting fields needed organizations that, through publications and shooting programs, would make marksmanship an acceptable activity for boys. The emerging triangle of the NRA, the BSA, and the gun and ammunition manufacturers provided the images, narratives, and programs that accomplished this for the American middle class. 


\section{The National Rifle Association}

Two Union army officers - Col. William C. Church and Gen. George Wingate - who were displeased with the marksmanship of the average soldier in the Civil War, founded the National Rifle Association in 1871. Through his publication, The Rifle Magazine (which, after other name changes, became The American Rifleman in 1924 when purchased by the NRA), Arthur Corbin Gould advocated marksmanship training as a means to build strong, masculine citizenship in an increasingly uncertain era. ${ }^{7}$ Corbin and others (including the Colt Firearms Company) sought to make the American rifleman a moral hero, attaching to rifle practice and competition the virtues of the self-disciplined, democratic manhood that needed to be restored in the decades following the Civil War, decades marked by economic uncertainty, increased immigration, urbanization, and social Darwinian worries that modern society was feminizing American men. "As disciplined recreation," notes one historian, "competitive rifle shooting encouraged habits that the business class liked." Always in the midst of this movement to revitalize American manhood through outdoor activities, Theodore Roosevelt created the National Board for the Promotion of Rifle Practice in $1903 .{ }^{9}$

Also in 1903, the NRA's youth programs were founded. NRA Secretary Albert S. Jones "urged the establishment of rifle clubs at all major colleges, universities, and military academies." ${ }^{10}$ By 1906, the NRA was sponsoring competitive shooting matches for the boys in the junior program. In the next few decades, the NRA expanded its youth programs to include girls.

\section{Enter Scouting}

In the summer of 1907, Lord Robert Baden-Powell, the military hero of Mafeking (a legendary siege and battle in the Boer War in South Africa) acted on his idea that England needed a youth movement to create young men physically fit and prepared to defend the Empire. He despaired that many of the young men he saw in the British army had been made too soft by modern life, and he sought to restore in British youth the fitness and manliness that created and sustained the Empire. ${ }^{11} \mathrm{He}$ had been working on a draft of a handbook for an organization he planned to call the Boy Scouts (after the military scouts he used in the Boer War), and in that summer of 1907 he took a few dozen boys to Brownsea Island for a campout meant to try out some of his ideas about activities (including games) that would train boys in observation and survival skills in the wilderness. The camp was a great success in his view, and the next year he founded the organization and published his handbook for the movement.

Baden-Powell was careful to avoid the direct military trappings that would make British parents worried and stir antimilitary sentiments in England. Gun ownership has a different history and set of customs in Great Britain than it did in the United States, so in any case guns would not play an important role in the organization. Baden-Powell did want British youth to become able marksmen, 
and he did design a Boy Scout uniform resembling a military uniform, but he also took pains to declare that his were "peace scouts." 12

When a group of lawyers, businessmen, and youth workers founded the Boy Scouts of America (BSA) in 1910, largely in response to the same worries about the effects of modernity on manhood and self-reliance that motivated Baden-Powell, they faced a culture in which gun ownership and use were far more taken for granted than they were in England. Still, several social factors helped determine the course the founders were to take regarding guns and shooting. First, they were creating a movement designed to serve urban and suburban youth. Rural youth, who were raised in a hunting culture and who were familiar with guns and gun safety, were not the audience for the Boy Scouts of America. The movement was for the boys who had paid the price of urban civilization and who were far removed from the wilderness experience that fostered manly virtues like self-reliance and physical fitness. Popular ideas drawn from Darwinism informed this notion of an enervated modern youth, but the founders of the BSA also intended the organization to "Americanize" the urban immigrant boys flooding American cities.

Second, there was a strong antimilitarist sentiment among some of the founders, especially Ernest Thompson Seton. Antimilitarism, outright pacifism, and American isolationism as the United States watched Europe slip toward war all played a part in the BSA's distancing itself from guns, while at the same time promoting patriotism. ${ }^{13}$ Until it received a charter from Congress in 1916, which guaranteed its monopoly on the "Boy Scout" name, the BSA was in competition with at least four other "Boy Scout" organizations, all of them militaristic. ${ }^{14}$ The accidental shooting of a small boy by an American Boy Scout (a rival organization created by William Randolph Hearst) in 1912 made all the more important the BSA's distancing itself from militarism and guns. ${ }^{15}$

So at its founding the BSA needed to include guns in its program while avoiding as much as possible any indication that the BSA was a paramilitary organization. A rhetoric linking rifle marksmanship to responsible democratic citizenship and to masculine virtues of self-control and self-reliance provided the BSA with the perfect solution. The first edition (1911) of the BSA's Official Handbook for Boys included marksmanship as one of the first merit badges a boy could win, though under the requirements for earning the badge, the Handbook authors say simply "Qualify as a Marksman in accordance with the regulations of the National Rifle Association." ${ }^{.16}$ From the moment of its founding, the BSA collaborated with the NRA in normalizing rifle use and safety for young men.

It is interesting that the BSA never embraced hunting as part of its program, despite Dan Beard's presence as a founder and his use of the frontiersmen in his precursor organization, the Sons of Daniel Boone (1905). Perhaps this was because of the greater power Chief Scout Ernest Thompson Seton enjoyed in the first two years of the organization. Seton held the Native American rather than the white pioneer as the model of white, moral, physically fit manhood. 
Seton, as artist and naturalist, was something of a pacifist, and he objected to the BSA's adopting a military-style uniform resembling the British Boy Scout uniform created by Baden-Powell. Seton also objected to military-style drilling and other elements involving guns. ${ }^{17}$ Rowan notes that pressures from Andrew Carnegie and the peace movement probably are the reason why the BSA awarded very few Marksmanship merit badges in the first few years of the organization's existence and the reason why the BSA refused to adopt an "American Boy Scout" model .22 caliber rifle designed and marketed by Remington Arms. ${ }^{18}$

\section{A New Market for Guns and Ammo}

As is clear from the effort by Remington to identify the Boy Scouts as a market for their rifles, the major gun manufacturers, ammunition manufacturers, and the Daisy Company (makers of air-powered BB guns) collaborated to help naturalize rifle shooting among the urban and suburban youth who were becoming Boy Scouts. Remington put a full-page advertisement in the first Handbook for Boys, emphasizing qualities such as "Quickness of eye, steady judgment, [and] self-confidence." 19 An advertisement for "Boy Scout Cartridges" placed by the United States Cartridge Company in St. Nicholas Magazine in the same period features a drawing of Boy Scouts camping out and enjoying fishing and target shooting. "Boy," exclaims the advertisement copy, "here's the best kind of outdoor fun - rifle shooting. It gives you what you've always wanted-and ought to know how to handle - a gun. Tell your parents that proper rifle instruction and target practice make you careful and responsible - give you courage and self-reliance - train your eye and teach you how to control your nerves." 20 Daisy Air Rifle advertisements from the same era also invoked the BSA program and touted the virtues of marksmanship. In a nearly full-page ad in The American Boy from the period, there is no explicit claim of endorsement from the BSA, but the drawing accompanying the ad copy shows a boy's room with a Daisy rifle on the desk and a framed picture of a Boy Scout holding a Daisy rifle. "The Happy Daisy Boy," proclaims the caption on the picture, and the ad copy itself makes the claims we see in the firearms ads. "Dad had a Daisy thirty years ago," claims the ad.

And the Daisy looks like a real gun and shoots just as true in its range. It makes your eyes clear and sharp and keen. It fires the imagination. It gets you into the great outdoors. It steadies your nerves. It makes you ready for the big gun-the kind Dad uses now.

Tell Dad that a Daisy is the first step towards upright self-control and manliness.

Tell Dad that you want a Daisy-tell him that you want as much good, clean fun, and as much chance to be a man, as he had..$^{21}$ 
The Daisy Manufacturing Company, which began as a windmill company in Michigan in 1882, saved itself from economic ruin by creating and marketing in 1888 a metal air rifle that soon became very popular. ${ }^{22}$ The lever action repeater rifle Daisy introduced in 1903 was enormously successful. They introduced a pump action gun (Model 25) in 1914 and sold more than eight million of these by the time they were discontinued in 1979. Throughout the 1930s and 1940s, the firearms manufacturers continued promoting gun ownership and safe marksmanship training for young people, but it is fair to say that it was the Daisy Manufacturing Company that kept rifles in the hands of boys during the Depression and in the years just before World War II. Their partnership with the BSA and the NRA was crucial to this success.

\section{The 1930s and 1940s}

By 1930, the BSA was publishing Merit Badge Pamphlets that provided instruction beyond the list of requirements the boy could find in the Handbook. The 1930 twenty-six page "Marksmanship" pamphlet picks up the themes from twenty years earlier. After justifying learning the skills for the badge in terms of gun safety, the author of the pamphlet reflects on other goals. "From the physical side," writes the author,

there is much to be said for rifle practice. To become a good marksman one's nerves must be in good order, eyes clear, muscles under control - in fact, there must be almost perfect coordination of all parts of the body....

It must be recognized, though, that marksmanship is a means to an end, but by no means the end. Scouts are encouraged to learn to handle the rifle, not that they may become experts in shooting, but that in becoming experts, they may learn to take care of themselves and others; that they may acquire the physical perfection without which good shooting is next to impossible, and that they may have still one more form of competition to stimulate their progress in Scoutcraft. $^{23}$

In the 1930s and 1940s, rifle ranges became common at Boy Scout camps, these ranges usually affiliated with the NRA. Meanwhile, the NRA was developing summer camp activities of its own. The 1941 Junior Rifle Handbook establishes the themes of national citizenship and patriotism. "Everyone is familiar with the story of the riflemen who explored this great country of ours," begins the handbook, "risking their lives to build a single nation extending from the Atlantic to the Pacific Coast. Such outstanding frontiersmen as Daniel Boone, Simon Kenton, and Kit Carson are rightfully the heroes of every American boy and girl." The author then goes on to establish George Washington as an expert 
rifleman, meaning to establish the original intent to establish the Constitutional right to bear arms. "We might trace the history of American independence from that day to this in the history of America's riflemen."24

The 1941 NRA Junior Rifle Handbook makes clear the ways the NRA had made itself part of the youth programs of several organizations, both for boys and for girls, on the eve of America's entry into World War II. The handbook advises boys and girls to do their shooting as a member of a Junior Rifle Club, most often found in schools, Boy Scout troops, Girl Scout troops, YMCA chapters, Sunday schools at churches, and summer camps. ${ }^{25}$ The iconography of the NRA Club Charter, as shown in the 1941 handbook, was repeated in the membership certificates of accomplishment issued to individual members. On the left is the Minuteman, the NRA's central symbol of the link between rifle skills, the birth of the nation, and patriotic citizenship. The rest of the drawings on the group charter and the individual certificate illustrate the benevolent guidance adult men provide boys and girls in acquiring skills handling and shooting rifles. That the figures are all white is not surprising, given the period. And despite the one boy's wearing overalls - a possible sign of rural or working class origins - the dominant feature of target shooting suggests that the youth movements serving these youth are in cities and suburbs. Put differently, we see no reference to rural America and hunting in the iconography - no farm youth organizations appear on the list, and hunting is scarcely mentioned. The .22 caliber rifle is primarily for shooting targets and the occasional varmint.

Remarkably, the line drawings illustrating shooting positions in the 1941 NRA handbook appear to be Boy Scouts, with the campaign hats, neckerchiefs, and style of pants commonly worn by Scouts. The NRA drawings are not identical to the drawings in the 1930 Marksmanship merit badge pamphlet, but they are very close. The reader of this handbook could have no doubt about the ways the BSA and the NRA were building a single youth rifle-shooting program for boys.

A sense of historical continuity with a romantic, heroic past based on the rifleman must have been very important to Americans experiencing the deprivation and pessimism of the Great Depression. The NRA and BSA accommodated this need. The entrance of the United States into World War II prompted the same sort of efforts by the Boy Scouts the citizenry saw in World War IBoy Scouts helping sell Liberty Bonds, Boy Scouts collecting scrap needed for the war effort, and so on. As in World War I, the BSA was careful not to turn the organization into a paramilitary organization preparing American boys to be soldiers. ${ }^{26}$ The war experience, however, did provide a whole new set of narratives and images for the Baby Boomers coming of age in the 1950s and 1960s.

\section{The Fifties}

If the eagerness to train American youth how to shoot rifles safely and skillfully has intensified during periods of cultural anxiety about masculinity, 
then postwar America provided the perfect scene for efforts to naturalize rifle shooting for urban and suburban youth. Historical scholarship on the 1950s has established quite thoroughly the social and historical conditions that raised anxieties about American manhood. ${ }^{27}$ The fifties did not experience the severe economic conditions of uncertainty that fueled the 1890s panic about American manhood, but other familiar conditions were present. In the workplace, men increasingly found themselves in bureaucratic, white-collar settings, farther and farther removed from "manly" work. The suburbanization of white, middleclass America and the rise of what Betty Friedan called "the feminine mystique" meant that boys were being raised primarily by mothers and by female teachers, conditions ripe for "feminizing" the American boy. ${ }^{28}$

This anxiety about the feminization of American men and boys had an urgent political dimension in the 1950s. The rhetoric of the Cold War was filled with talk about strength and weakness, about "hard" and "soft" bodies, about "hard" and "soft" stances toward Communism, and about aggressiveness and passivity. A strong America required strong male bodies that embodied (literally and metaphorically) American national identity and American virtuesindependence, self-reliance, moral strength, and reverence for God. The wellknown campaigns against male homosexuality in the 1950s reflected the panic that American males might not be strong enough (masculine enough) to stand up for America in the Cold War with worldwide Communism. ${ }^{29}$

The iron triangle of the Boy Scouts, the NRA, and the gun and ammunition manufacturers responded to this crisis with renewed energy toward teaching American virtues through rifle marksmanship. Their campaign would be helped by the lingering images and narratives of World War II that the early Baby Boom generation consumed in the 1950s and early 1960s. Unlike the present, with debates whether toy guns and other war toys are bad for boys, the middleclass suburban parents of the 1950s gladly bought toy guns and plastic armies for their boys. The new entertainment medium of television was hungry for programming, so many stations played Western films and World War II films throughout the 1950s and into the 1960s. Middle-class boys brought up in the 1950 s can provide plenty of testimony about the hours spent playing "cowboys and Indians" or "World War II" in the woods and fields adjacent to the suburban middle-class housing developments in which the Baby Boomers (born 1946 to 1964) were coming of age. At least two Vietnam War memoirs-Tobias Wolff's In Pharaoh's Army (1995) and Ron Kovic's Born on the Fourth of July (1976) - recall the hours spent playing soldier in their Baby Boomer youth, and John Wayne (hero of both the Westerns and the World War II films of the 1940s and 1950s) became the figure invoked by Vietnam soldiers to describe officers who had a "John Wayne syndrome" and led soldiers recklessly into attacks. ${ }^{30}$ George Lucas confesses to having been raised on Western films and World War II films in his Boomer youth, and the imagery and dialogue from his Star Wars films bears that viewing experience (along with television showings of the "Flash Gordon" serials with Buster Crabbe). 
In short, when Daisy and the gun manufacturers set their sights on the emerging and affluent youth market of the 1950s, plenty of cultural images and mythologies were in place to help naturalize the presence of rifles in young hands. People relied upon those images and mythologies to allay the fears and anxieties Americans were feeling amid the normalcy and affluence of middleclass life in the 1950s, anxieties regarding masculinity, self-reliance, and national integrity. The boy's body came to stand for both these anxieties and their solution; the boy holding a rifle was as independent and dependable an image of strength as they come.

The 1950s revised version of the NRA's Junior Rifle Handbook was prepared to make the case for the importance of learning how to shoot rifles. The "Code of the Junior Rifleman" published in the 1950s handbook includes as number ten this pledge: "I will do my part to make America, once again, "A Nation of Riflemen." "'31 Gone are the drawings of Boy Scouts illustrating the shooting positions (replaced by boys wearing appropriate shooting jackets), and the 1950s handbook highlights girls' shooting clubs and camps more than the 1941 handbook, but the patriotic message remained the same.

The 1950s was a golden era for the Boy Scouts, not least because the organization wed the American civil religion, patriotic nationalism, and manliness. With the violence of World War II still fresh in people's minds, rifle marksmanship had to be naturalized again to fit the 1950s emphasis on normalcy and the suburban nuclear family. The "1953 revised" version of the Marksmanship merit badge pamphlet retains much of the justificatory rhetoric of the 1930 pamphlet: "To become a good marksman your nerves must be in good order, eyes clear, muscles under control - in fact, there must be almost perfect coordination for all parts of your body."${ }^{, 32}$ Here are all the cultural themes of the $1950 \mathrm{~s}$ embodied in the boy rifle marksman - control, physical fitness, and mental clarity (presumably not clouded by alcohol or other drugs).

The 1953 pamphlet makes the case for rifle shooting as a sport for the whole family. Warning of the need for everyone, boys and girls alike, to be trained in gun safety ("Almost all men and women, sometime during their lives, hold firearms in their hands"), the authors of the pamphlet then tell this story:

A Scoutmaster of one Pennsylvania Scout Troop, checking up, found that seventeen of the twenty-four members of his Troop, which was sponsored by one of the local churches, owned rifles of .22 caliber. Only two of these had received instructions in its proper use. On recommendation of the Troop Committee, a range was installed in the basement of the church. Here not only Scouts but also their sisters and parents enjoy the sport. As a matter of fact rifle shooting is one of those all too rare sports which father and son, mother and daughter can enjoy together and with equal chance of success. ${ }^{33}$ 
Condensed in this brief anecdote are several important themes of the 1950s. The Boy Scouts and religion are linked through the church sponsorship, and the church blesses rifle shooting by permitting a shooting range to be built in its basement. If a theme of the 1950s was "a family that prays together stays together," then we might say that the message of this story is that the nuclear family that shoots together stays together.

One of the paradoxes in this 1953 BSA rhetoric is the inclusion of young women among those who can benefit from organized marksmanship training and competition. Marksmanship and the BSA programs clearly address the masculinity anxieties of the 1950s, but why include sisters and mothers? Several conflicting forces are at work here. The 1950s emphasis on the nuclear family equated the strength of the family with the strength of the nation, and the family needed "wholesome" activities to bring them together. ${ }^{34}$ The skills required for target shooting tend to minimize the advantages men have over women in most competitive sports, and the inclusion of women in this sport did not threaten to feminize the American boy. The inclusion of women in this pamphlet also anticipates a move the BSA made in the 1960s, creating portions of the program for adolescent women. The BSA had long recognized that they begin losing the boy at age fifteen or so, when high school activities and the attention of girls compete for the boy's time. The creation of a coeducational Explorer program and, later, coeducational Venture Scouting has represented the ongoing attempts by the BSA to include the girls, in large part to keep the boys.

Although the 1953 pamphlet endorses hunting as "an ancient and honorable sport," notes the importance of gun safety in the field, and illustrates the rules of gun safety with photographs of hunters (a departure from the earlier stance of the BSA regarding hunting), the focus is still on target shooting with the .22 rifle. The pamphlet closes with a section on the NRA and recommends that the Scout find an NRA-chartered "Scout Rifle Club" as the best place to do his shooting. ${ }^{35}$

Meanwhile, the Daisy Manufacturing Company was collaborating with both the NRA and the BSA to make the Daisy air rifle an acceptable substitute for the .22 caliber rifle in youth shooting programs. Through the first half of the twentieth century, Daisy continued advertising its air rifles in the magazines aimed at boys, and the comic book craze of the 1950s provided an excellent new venue for those advertisements. As earlier, the Daisy ads often tapped the American mythologies and images of the West, producing air rifles that resembled famous rifles by Colt and Remington. Christmas catalogs and newspaper advertising supplements marketed the Daisy air rifles to boys, and it was an almost universal white, middle-class boy's wish to find a Daisy air rifle under the tree come Christmas morning.

The Daisy Company cleverly saw the emerging middle class culture of the 1950 s as the perfect setting for raising the air rifle from the status of toy to that of a more serious recreational product. To accomplish this, the Daisy Company 
needed respectable organizations like the BSA and the NRA to embrace the air rifle in their youth shooting programs.

A four-paneled brochure (ca. 1951) published and distributed by the Daisy Company explains how the Daisy air rifle can be incorporated into the NRA Junior Rifle Patrols for boys and girls under 19 years of age. "The Daisy Air Rifle is essentially a piece of juvenile sporting equipment," explains the brochure; "it is not a toy and yet it is designed primarily for fun. It is not a lethal weapon, but it is a gun and, as such, it commands the respect due to all guns" (bold in original).$^{36}$ The Daisy marketers were keen to associate the positive virtues of rifle shooting with their air rifles, including learning gun safety, acquiring "an appreciation of the meaning of sportsmanship," and the thrill of mastering a skill. The Daisy people convinced the NRA that a fifteen-foot air rifle range required the same shooting skill as did a fifty-foot .22 caliber rifle range, so the air rifle program could use the NRA targets and requirements for patches and medals indicating levels of proficiency in rifle shooting.

A 1959 pamphlet published and distributed by the Daisy Company affirmed the positive values of including the air gun in the middle-class home and its nuclear family. The cover photograph itself places the Daisy air rifle into the family tableau, with a married couple smiling with pride as their son shows them the target he has just shot using the rifle that rests across his thigh. The father's light grasp on the end of the lever-action rifle's stock completes the connection - the viewer's eye moves from parents to rifle to son and back to parents through their loving gaze. ${ }^{37}$ The rifle takes the place of the pet in this middle-class living room, with an indoor Daisy shooting range backstop against the back wall, alongside a bookcase of books. This image alone would be enough to domesticate the Daisy air rifle, but the pamphlet's text assures parents that a "shooting program should offer a wholesome sport, fun for the shooter, a test of skill and marksmanship and a lasting lesson in good gun handling." ${ }^{38}$ The pamphlet explains how the Daisy spring-loaded (not stored compressed air) air rifle used in a fifteen-foot range can meet all of the requirements of the NRA for the programs on the .22 caliber fifty-foot range. The pamphlet emphasizes that adult instructors should be present, explains how to set up a safe range, illustrates firing positions, and explains how to care for the gun. The last few pages of the pamphlet give the boy and his father the opportunity to order the indoor range pictured on the cover or to order Daisy guns. By the 1953 Marksmanship merit badge pamphlet's publication, the BSA had accepted the fifteen-foot range spring-loaded air rifle as a substitute for the .22 caliber rifle in meeting the merit badge requirements. ${ }^{39}$

The gun manufacturers and their trade organizations had their own campaign in the 1950 s to domesticate the .22 caliber rifle. A comic book published and distributed by the Remington Arms Company is entitled "How to Shoot" and promises "Good Eyes, Good Health, Good Sportsmanship, and Good Friends." ${ }^{40}$ The cover drawing, shown in Figure 1, shows a teenaged boy and girl, each holding a .22 caliber rifle, and behind them are the "spirits" of the 
heroes of the American West. "Remington rifles helped blaze the trail to America's glory," proclaims the cover. The smiling kids could not be happier. The comic book covers all the safety rules, shooting positions, setting up a range, and the fundamentals of shooting. The comic ends with an endorsement of the NRA Rangers program for youth and explains where boys and girls can send their targets to earn their emblems and badges.

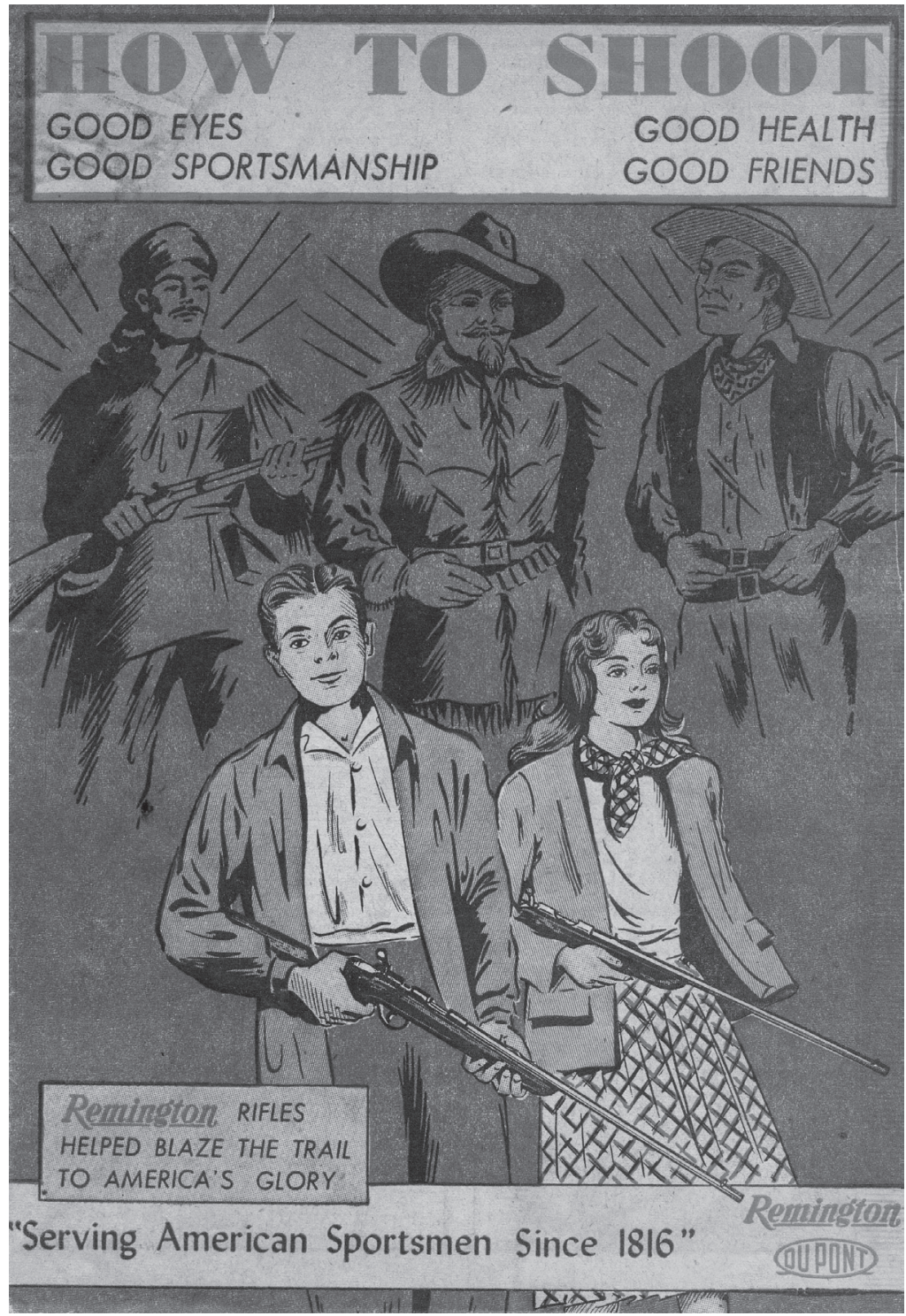

Figure 1: Cover, "How to Shoot" comic book, Remington Arms Company, c1950. 
The Sporting Arms and Ammunition Manufacturers Institute- the trade organization for Remington, Winchester, and other companies - produced its own comic books, including one entitled "More Fun with Your 22 Rifle," full of safety tips, shooting instruction, tips on cleaning the rifle, and games and competitions to make shooting more fun.$^{41}$ On the cover a father points toward a target his son (presumably) is shooting at, while a woman dressed in blue jeans (a sister, a mother?) rests with her rifle and looks at the targets she has just shot. Inside, a drawing of a mounted, buckskin-garbed scout holding his rifle, with a wagon train in the background, connects this modern target shooting with that romantic mythology of the West.

The postwar strategy of the BSA, the NRA, and the gun and ammunition manufacturers to "domesticate" the .22 rifle and to naturalize shooting among suburban preadolescents and adolescents tapped American mythologies and continued the emphasis on the distinctly American virtues - physical fitness, clearheadedness, self-discipline, and self-reliance - touted by rifle marksmanship advocates since the 1890s. The campaigns also responded to a new context, to the iconographic suburban nuclear family, including the mother and daughter, and to the value of a wholesome, clean sport that everyone in the family could enjoy. Target shooting was an oddly equalizing sport for women and girls, as nothing kept them from shooting as well as the men and boys so long as the rifles were light enough that they did not require a great deal of strength to carry and shoot. Both .22 rifles and air rifles were light enough for the girls, though boys still outnumbered girls in the youth rifle programs.

\section{The Sixties and Seventies}

The increasing urban violence of the 1960s and the rise of the antiwar movement began to put recreational target shooting in a new light, and not always a flattering one. Toy manufacturers in the 1960s certainly felt pressure as parent groups and peace advocates lobbied against toy guns and other war toys. The BSA and the NRA continued running their youth programs, and Boy Scout summer camps still featured rifle ranges, but the tone of advocacy was reduced considerably.

The first few years of the 1960s saw only hints of the coming violence, and the events of November 22, 1963, seem in retrospect to signal the change. Just a few months before the Kennedy assassination, the Daisy Manufacturing Company managed to get a feature article on their air rifles in the April 1963 issue of Sports Illustrated, giving prestigious support to the company's claim that the Daisy rifle was not a toy (even though its marketing appeared otherwise). "One of the company's continuing worries, of course," explains the author,

is that creeping urbanization and restrictive ordinances simply will make it impossible for kids to use air guns. It has met this problem head on with a program which upholds Daisy's 
highest traditions: it sells a mess of air guns and it teaches youngsters sportsmanship, marksmanship and correct gun handling. This is Daisy's widely praised Training Services program. ${ }^{42}$

Daisy worked with community organizations to set up these youth programs. Complicating things for the BSA in the 1960s was their effort to recruit more urban boys, especially African American and Latino boys in the inner cities. Despite some exceptions, such as "Negro troops" and some Asian American troops, for decades since its founding the BSA was a white, largely middleclass youth organization. As racial segregation in the United States came under increased scrutiny and the Civil Rights movement grew, the BSA leadership realized that the changing conditions for boys growing up in the United States required new initiatives. At its annual meeting in 1968, the BSA adopted an eight-year program called BOYPOWER ' 76 , leading up to the country's bicentennial celebrations. ${ }^{43}$ The results were mixed, and by the early 1970 s the program was plagued by financial scandals, but the initiative indicates that the BSA leadership recognized that they needed to change with the times: the 1960s were far from the 1950s, and the BSA struggled to define its role in the changing demographics of American boyhood.

The 1967 edition of the Marksmanship merit badge pamphlet - the first new edition since 1953 - clearly tries to respond to the times. In fact, the name of the badge changed from "Marksmanship" to "Rifle and Shotgun Shooting." Gone are invocations of the American past and the virtues of fifties America that could be strengthened by competitive rifle shooting. As always, the emphasis of the pamphlet was on the safe handling of guns and on the proper techniques for shooting, but the authors of the pamphlet also recognized the changing meanings of guns in American culture. The Kennedy assassination in 1963, the visual presence of firearms in the clashes of the Civil Rights movement (to say nothing of the presence of guns in the Black Power movement), and the political assassinations of 1968 left no opening for a romantic, nostalgic view toward guns in America.

The first and new requirement in the 1967 pamphlet, for example, asks the Scout to "[e]xplain the general features of the laws governing the use and possession of firearms in your community." ${ }^{44}$ The text accompanying this requirement notes that earlier in American history most people could carry a gun and use it for protection against animals and "lawless men." Present-day law and order, continue the authors, makes less important the need for everyday carrying of guns. "Because guns have been used hastily in moments of anger or handled by people without proper knowledge of their use," the author explains, "most communities have found it necessary to limit the normal carrying of a concealed weapon to those who have a real need." Communities found it necessary to restrict "how and where you can shoot a gun." 
It is significant that the BSA author makes no other comment on the emerging gun control laws of the 1960s. The NRA was fighting those laws, but the whole 1967 BSA pamphlet distances itself from the NRA in ways quite unlike earlier pamphlets. The pamphlet mentions in passing NRA standards for camp shooting ranges and NRA official targets, but by this time there were also official BSA targets that could be used. The pamphlet has no special section on the NRA, as did previous pamphlets, but instead merely mentions the NRA among other organizations in a brief section on "Shooting Helps."

This distancing of the BSA youth shooting program from the NRA is all the more remarkable because the 1967 pamphlet opens a shotgun option for earning the badge, and the shotgun sections clearly are aimed at skills and safety rules for the boy hunter. The BSA, recall, had from 1910 excluded hunting from the Handbooks and the Marksmanship merit badge requirements, even though the rifle and ammunition manufacturers put Boy Scouts into hunting scenes in their advertisements. One reason for the change in the 1967 pamphlet may be the fact that in the 1960s the hunting community and businesses had developed a persuasive rhetoric of the value of sport hunting for wildlife conservation. One of the requirements for the badge (from 1967 to 2001, when the Rifle Shooting and Shotgun Shooting badges were made separate) is to "[e]xplain how guns are related to wildlife conservation." ${ }^{\prime 4}$ The message in the accompanying text is that hunting can help maintain healthy populations of wild animals. Scouts also have to show they are familiar with the hunting regulations of their states. The pamphlet instructs the boy on the qualities of "a good sportsman"-all the safety and courtesy the hunting community had come to expect to keep hunting acceptable in the face of antihunting sentiments and even antihunting organizations.

In many ways, the 1950 s were the golden age of sport hunting for the middle class. Sport hunting in the late nineteenth and early twentieth century was a pastime of the elite, but a number of factors (not least the experience of many young men with rifle training in the war) led to the marketing of hunting as a wholesome sport for the whole family. The NRA began its hunter education program in 1949 as part of an effort to persuade the postwar public that sport shooting was safe. ${ }^{47}$ The rhetoric justifying hunting resembled the earlier rhetoric recommending rifle shooting; which is to say that sport hunting was not about killing animals but was about a reconnection with nature, a sense of selfreliance, the self-discipline it takes to hunt, and the camaraderie of the hunting party. $^{48}$

Another departure of the 1967 pamphlet from previous ones was the inclusion of handguns. The author warns the Scout about the "difficulty in safe handling and difficulty in shooting well" when using handguns and strongly advises mastery of rifle shooting before using handguns for target shooting. ${ }^{49}$ The attention to the safe handling and storage of handguns in the 1967 pamphlet reflects, no doubt, the increasing presence of handguns in middle-class American homes, so rather than ignore the handguns already wreaking such havoc 
in American cities, the BSA elected to do what it could to educate boys about those guns.

The one connection the 1967 requirements make to the romantic past of America's firearms is the inclusion of muzzle-loaded guns, though as more of a novelty than as a skill requirement. There is no romantic rhetoric surrounding these old-style guns in the pamphlet. The target shooting still requires rifled guns (as opposed to the smoothbore muzzle-loaders with round shot), but in the safety requirements the boy has the option of showing he can safely handle a muzzle-loaded gun. Some BSA camps offer the opportunity to load and shoot muzzle-loaded guns (sometimes called "black powder" guns).

So while the BSA did not abandon altogether the earlier rhetoric about a nation built by self-reliant riflemen, the social and cultural circumstances of the 1960s required a presentist approach to safety and the values of sport hunting for boys and girls alike. This safety-oriented rhetorical strategy came to dominate the BSA and even the NRA discourse in the ensuing decades.

Even though the Boy Scout publications were abandoning the romantic rhetoric of the role of guns in American history, the gun manufacturers still used that appeal in their advertising. A full-page ad in the June 1964 issue of Boys' Life, the official magazine of the BSA, features a color photograph of a Boy Scout holding and aiming the Ithaca Gun Company's "Saddlegun" model .22 lever-action rifle, "styled after the famous gun that laid down the law in the early West."

\section{The Eighties to 2001}

Many historians, literary critics, and media critics have noted the "remasculinization" of American culture in the Reagan years (1981-89), an assertive masculinity responding to "the Vietnam syndrome" of loss (emasculation) and to a changing economic system in the $1970 \mathrm{~s} .{ }^{50}$ Guns became a part of that remasculinization. In his 1994 book about this phenomenon, James William Gibson enhances his analysis of public discourse and popular culture by actually doing fieldwork in settings where men were enacting this violent masculinity. ${ }^{51}$ Gibson interviewed paintball players, combat pistol shooters, mercenaries, and members of right-wing militia groups to show the seductive power of guns to men who were feeling increasingly alienated from American culture. "Imaginary wars" were a poor substitute for real wars as proving grounds for masculinity, but it was all these men had until the Gulf War of 1991.

The BSA continued to be cautious in this era of increasing private and state paramilitarism. The BSA Rifle Shooting and Shotgun Shooting merit badges became separate by 1989. The Rifle Shooting Merit Badge pamphlet from that era emphasizes safety and the mental and physical elements of target shooting. ${ }^{52}$

The gun manufacturers continued to treat Boy Scouts as an important cadre of customers. In 1985 the Winchester Firearms Catalog introduced two limited edition models of .22 caliber rifles to celebrate the seventy-fifth anniversary of 
the founding of the BSA. One was designated the "Eagle Scout Limited Edition," and the other was the "Boy Scouts of America Commemorative" model. The lever-action guns themselves have engraved side plates with Boy Scout icons, a use of images that must have been approved by the BSA leadership. ${ }^{53}$

\section{1 to the Present}

The 2001 Rifle Shooting Merit Badge pamphlet makes many references to the NRA, including requiring that "all training and shooting activities must be supervised by a currently certified NRA rifle instructor or NRA coach who is 21 years of age or older." ${ }^{54}$ At the very end of the pamphlet, the BSA acknowledges the help of many experts in writing this revised pamphlet, including NRA experts, and the photograph accompanying the acknowledgments is of six adult leaders and older Scouts standing behind a large sign for the NRA's "National Firearms Museum."

Gone from the 2001 pamphlet is the long discussion from 1967 of the gun laws in states and municipalities. At the same time, the 2001 pamphlet is a strictly technical instructional manual; gone is any rhetoric justifying rifle shooting as part of American history. The authors of the 2012 pamphlet adopt that same instructional tone..$^{55}$

Meanwhile, in May of 2009, the BSA suddenly faced embarrassing publicity involving Scouts and guns. The Explorer Program, a coeducational branch of the BSA for adolescents ages fourteen to eighteen, often has "Posts" (as opposed to Boy Scout "troops") sponsored by organizations introducing young people to possible careers, including law enforcement. Such a program in Imperial, California, was sponsored by the Border Patrol and was training young men and women in weapons use and tactics devoted to fighting terrorists and tracking down "illegal immigrants." 56 This was one of more than 2,000 lawenforcement Explorer posts serving 35,000 adolescents as young as fourteen. The public did not respond well to the story and images of teenagers in battle vests and realistic model assault weapons. Nor did the focus on intercepting "illegal immigrants" help the BSA's new initiative to recruit more Latino Scouts and volunteer adult leaders, recognizing the growing importance of that demographic group that has been underserved by Scouting. ${ }^{57}$

\section{Conclusion}

The NRA's tough, uncompromising stance in reaction to the calls for more gun control in the wake of the mass shooting at Sandy Hook Elementary School in December of 2012 has put the BSA in something of a bind. It is still too early to tell (as of this writing) whether the fierce debate over gun control and gun safety will affect the BSA. NRA guidelines continue to have a presence in the Boy Scouts' shooting programs. At the Southern California Scout camp I attended in the summers of 2007,2009, and 2010, the posted range rules were the NRA's, with the NRA name prominently displayed. Boys now shoot with 
safety goggles and safety ear protection. Parents still sign releases for their sons (and some daughters) to shoot rifles, BB guns, and arrows (in archery), but most parents seem to have accepted shooting guns as a normal, natural part of the Boy Scout camp experience. The debates over toy guns and first-person shooting games (video and computer) rage while tens of thousands of parents sign up their sons and daughters for marksmanship training.

If anything, the gun and ammunition manufacturers have stepped up their efforts to recruit a new generation of young shooters, publishing a magazine, Junior Shooters; giving firearms and ammunition to youth groups; sponsoring shooting competitions; and marketing rifles specifically designed and advertised to appeal to young shooters. ${ }^{58}$ The number of households in the United States with guns has declined; at the same time, gun owners possess increasing numbers of guns. The most dramatic decline in gun ownership has been among Americans under age thirty. ${ }^{59}$

Images of boys with guns conjure conflicting feelings in many Americans, but the overwhelming acceptance of target shooting as a wholesome sport is the product of over 100 years of persuasive narratives, images, and programs serving to make target rifles a natural, normal tool as the boy becomes the man. This "wholesome" image of boys with guns, we should note, applies mainly to white boys; images of African American boys or boys from other urban ethnic groups holding guns more likely evoke fear and anxiety than nostalgic comfort. The iron triangle of the NRA, the BSA, and the arms and ammunition manufacturers succeeded in large part by reading the culture correctly, knowing when to invoke a romantic history of riflemen, knowing when to tout the masculinizing effects of marksmanship, knowing when to emphasize the family, and knowing when to emphasize wilderness conservation and safety. The gun culture of the United States constantly evolves; each generation of boys needs to be socialized into the gun culture anew. First-person shooting games play a large part in the present socialization, but for thousands of Boy Scouts, it is at summer camp that the boy experiences the intoxicating feel and smell of a real rifle, the powerful talisman of masculinity.

\section{Notes}

1. Tim O'Brien, If I Die in a Combat Zone: Box Me Up and Ship Me Home (New York: Delacorte Press, 1975).

2. The BSA founders wanted to reach the urban poor kids as well as the rural kids, but these attempts were never very successful. By the 1950 s, the BSA was largely a white, suburban organization serving that new demographic, the white Baby Boomer. Attempts in the 1960s and 1970s to diversify ethnicity largely failed. Recently, the BSA tried to recruit members from the Hispanic/ Latino population, but the results have not been promising.

3. Jay Mechling, "Gun Play," American Journal of Play 1 (2008): 192-209.

4. The fiftieth anniversary of the speech in 2011 prompted renewed interest in the speech from journalists and historians. See James Ledbetter, Unwarranted Influence: Dwight D. Eisenhower and the Military-Industrial Complex (New Haven, CT: Yale University Press, 2011).

5. Michael A. Bellesiles, Arming America: The Origins of a National Gun Culture (New York: Knopf, 2000). This book became the target of a number of historians critical of Bellesiles's statistics and historical methods.

6. Daniel Justin Herman, Hunting and the American Imagination (Washington, DC: Smithsonian Institution Press, 2001). 


\section{Jay Mechling}

7. Joan Burbick, Gun Show Nation: Gun Culture and American Democracy (New York: The New Press, 2006), 35.

8. Ibid., 39.

9. Ibid., 43.

10. "A Brief History of the NRA," The National Rifle Association, last modified January 30, 2014, http://www.nrahq.org/history.asp.

11. Michael Rosenthal, The Character Factory: Baden-Powell and the Origins of the Boy Scout Movement (New York: Pantheon, 1986); Tim Jeal, The Boy-Man: The Life of Lord BadenPowell (New York: Morrow, 1990).

12. David I. Macleod, Building Character in the American Boy: The Boy Scouts, YMCA, and

Their Forerunners, 1870-1920 (Madison: University of Wisconsin Press, 1983), 139.

13. Ibid., 178-81.

14. Edward L. Rowan, To Do My Best: James E. West and the History of the Boy Scouts of America (Las Vegas, NV: Las Vegas International Scouting Museum, 2005), 30.

15. Ibid., 53-54.

16. Boy Scouts of America, The Official Handbook for Boys (Garden City, NY: Doubleday, Page \& Company, 1911), 36.

17. Jay Mechling, On My Honor: Boy Scouts and the Making of American Youth (Chicago: University of Chicago Press, 2001).

18. Rowan, To Do My Best, 54.

19. Remington ad in first Handbook for Boys, 1911, np.

20. An advertisement for "Boy Scout Cartridges" in St. Nicholas Magazine, author's collection.

21. Daisy ad in The American Boy, author's collection.

22. The Rogers Daisy Airgun Museum, http://www.daisymuseum.com/swf/default.htm. Accessed February 7, 2014.

23. Boy Scouts of America, Marksmanship (New York: Boy Scouts of America,1930), 1-2.

24. National Rifle Association, Junior Rifle Handbook (1941), 5. Author's collection.

25. Ibid., 6 .

26. Americans watched the German Boy Scouts in the 1930s be replaced by the Hitlerjungend (Hitler Youth), so they were wary of the militarization of the Boy Scouts.

27. There are many cultural histories of the 1950 s, but among the best are Paul A. Carter, Another Part of the Fifties (New York: Columbia University Press, 1983); William O'Neill, American High: The Years of Confidence, 1945-1960 (New York: Free Press, 1986); John Patrick Diggins, The Proud Decades: America in War and Peace, 1941-1960 (New York: Norton, 1988); and David Halberstam, The Fifties (New York: Random House, 1993).

28. Betty Friedan, The Feminine Mystique (New York: Dell, 1964).

29. Robert J. Corber, Homosexuality in Cold War America: Resistance and the Crisis of Masculinity (Durham, NC: Duke University Press, 1997).

30. Ron Kovic, Born on the Fourth of July (New York: Pocket Books, 1976); Tobias Wolff, In Pharaoh's Army: Memories of the Lost War (New York: Knopf, 1994).

31. National Rifle Association, Junior Rifle Handbook (Washington, D.C.: National Rifle Association, 1950), 43.

32. Boy Scouts of America, Marksmanship, Rev. by the National Rifle Association of America (New Brunswick, NJ: Boy Scouts of America, 1953), 1.

33. Ibid., 2.

34. Elaine Tyler May, Homeward Bound: American Families in the Cold War Era (New York: Basic Books, 1988).

35. Boy Scouts of America, Marksmanship, 62.

36. Brochure, Daisy Manufacturing Company, c. 1951. Author's collection.

37. Given the common understanding of the rifle as a symbolic penis, an equivalency bolstered by folk speech ranging from military cadences ("This is my rifle, this is my gun ...") to talk about an infertile man "shooting blanks," the positioning of the rifle near the boy's crotch and the father's touch on the stock suggests to me, at least, that a subliminal message of this image is that the father is passing on to his son the power of the penis/phallus in the family.

38. Daisy Manufacturing Company, "Daisy B-B Rifle Instruction Program" (Rogers, AK: Daisy Manufacturing Company, 1959), 1.

39. Boy Scouts of America, Marksmanship, 42-43.

40. Remington Arms Company, "How to Shoot," n.d., author's collection.

41. Sporting Arms and Ammunition Manufacturers Institute, "More Fun With Your 22 Rifle," n.d., author's collection.

42. Joe David Brown, "The Rifle Called Daisy," Sports Illustrated 18, no. 17 (April 29, $1963), 64$.

43. Boy Scouts of America, 1972 Report to Congress: Boy Scouts of America (Washington, DC: US Government Printing Office, 1972). See http://www.eric.ed.gov:80/ERICWebPortal/ 
custom/portlets/recordDetails/detailmini.jsp?_nfpb=true\&_\&ERICExtSearch_SearchValue_0=ED 095338\&ERICExtSearch_SearchType_0=eric_accno\&accno=ED095338.

44. Edward B. Crossman, Rifle and Shotgun Shooting (New Brunswick, NJ: Boy Scouts of America, 1967), 9.

45. Ibid.

46. Ibid., 10.

47. National Rifle Association, “A Brief History of the NRA," HYPERLINK "http://www. nrahq.org/history.asp" www.nrahq.org/history.asp, Accessed February 7, 2014.

48. See Jan E. Dizard, Mortal Stakes: Hunters and Hunting in Contemporary America (Amherst: University of Massachusetts Press, 2003); Jay Mechling, "Picturing Hunting," Western Folklore 63, no. 1-2 (2004): 51-78; and Simon J. Bronner, Killing Tradition: Inside Hunting and Animal Rights Controversies (Lexington: University Press of Kentucky, 2008).

49. Boy Scouts of America, Rifle and Shotgun Shooting, 69.

50. Susan Jeffords, Hard Bodies: Hollywood Masculinity in the Reagan Era (New Brunswick, NJ: Rutgers University Press, 1994).

51. James William Gibson, Warrior Dreams: Violence and Manhood in Post-Vietnam America (New York: Hill and Wang, 1994),

52. Boy Scouts of America, Rifle Shooting (Irving, TX: Boy Scouts of America, 1989).

53. Winchester Firearms Catalog (New Haven, CT: U.S. Repeating Arms Company, 1985), author's collection.

54. Boy Scouts of America, Rifle Shooting (Irving, TX: Boy Scouts of America, 2001), 2.

55. Boy Scouts of America, Rifle Shooting (Irving, TX: Boy Scouts of America, 2012).

56. Jennifer Steinhauer, "Scouts Train to Fight Terrorists, and More," New York Times, May 14, 2009, www.nytimes.com/2009/05/14/us/14explorers.html?_r=0 .

57. More recently, a Milwaukee Boy Scout troop got in trouble with the national office for creating an unauthorized "Border Patrol" patch featuring the iconic silhouette figures of a running family. See Georgia Pabst, "Milwaukee Boy Scout Troop's 'Border Patrol' Patch Causes Ire," Milwaukee Journal Sentinel, April 13, 2012, www.jsonline.com/news/milwaukee/milwaukee-boy -scout-troops-border-patrol-patch-causes-ire-3b50ads-147414825.html.

58. Mike McIntire, "Selling a New Generation on Guns," New York Times, January 26, 2013, www.nytimes.com/2013/01/27/us/selling-a-new-generation-on-guns.html?pagewanted=all.

59. Sabrina Tavernise and Robert Gebeloff, "Share of Homes with Guns Shows 4-Decade Decline," New York Times, March 9, 2013, www.nytimes.com/2013/03/10/us/rate-of-gunownership-is-down-survey-shows.html?pagewanted=all\&_r=0. 
